\title{
SOME OBSERVATIONS ON THE USE OF AM
IN URINARY TRACT INFECTIONS
}

\author{
Bryan C. StratFord \\ St. Vincent's Hospital, Melbourne.
}

AMPICILLIN was first introduced to the medical profession by Rolinson and Stevens in 1961 . At the same time Brown and Acred detailed the pharmacology of the drug and some animal protection studies. Knudsen, Rolinson and Stevens (1961) in discussing the absorption and excretion, showed the drug was well absorbed orally and pointed out that $30 \%$ of the administered dose was excreted in the urine within six to eight hours; this was the first indication that ampicillin might play an important part in the therapy of urinary tract infections. In the same issue of the British Medical Journal, Stewart and his colleagues (Stewart, Coles, Nixon and Holt, 1961) reported results of their studies in putting this hypothesis to the practical test of a clinical trial in patients with urinary tract and other infections.

Since these original publications a number of reports have appeared in the world medical literature dealing with the use of ampicillin in patients with both acute and chronic urinary tract infections.

We describe here the results of treating urinary tract infection with ampicillin at St. Vincent's Hospital, Melbourne.

\section{Materials and Methods \\ Sensitivity Discs}

Paper discs containing $10 \mu \mathrm{g}$. of ampicillin were placed on plates inoculated with a loop from an overnight broth culture of the organism under test. Zonal inhibition was determined after overnight incubation at $37^{\circ} \mathrm{C}$. This method was used throughout this series as it had already been shown (Rolinson and Stevens, 1961) that a reasonable correlation existed between disc sensitivities and M.I.C. values.

In a series of 150 isolates, discs containing 10,25 and $50 \mu \mathrm{g}$. of ampicillin were placed on the same plates to ascertain whether resistant organisms from urinary tract infections were in fact sensitive when higher disc concentrations of ampicillin were used. It was found that organisms were sensitive at 10 $\mu \mathrm{g}$. or not at all, so the standard disc remained a $10 \mu \mathrm{g}$. one.

\section{Collection of Specimens}

For the purpose of the present study on mid-stream urine specimens were used for detifmining the presence or absence of infection. Careful meatal cleansing was followed by the collection of the specimen into a sterile container which was immediately transferred to the laboratory for investigation. No catheterisation was employed.

The results of an earlier communication (Straford, 1962) confirmed the serum and urine levels of ampicillin reported by Knudsen et al. (1969) and Stewart et al. (1961), so microbiological assay of these body fluids was not carried out in the present study.

\section{Choice of Patients}

Patients were in the main chosen empirically fol the results of sensitivity tests performed in the tine bacteriology laboratory. Many had already been unsuccessfully treated with other antibiois, most were also acute cases although some were re-infections. No cases of true chronic urinary \#act infection were included in the series. The actual terminology used in the diagnosis was that of the physicians in charge of the patients and not nity own.

\section{Laboratory Diagnosis}

For some time a comparative study was pe्ठformed contrasting the results obtained with:

(a) Direct viable count of total organisms per mit of urine according to the method of Kass (1955)

(b) Urinary catalase reaction described by Braude and Berkowitz (1961)

(c) TTC reaction according to Simmons and W liams (1962)

(d) Routine high power examination of spun sedi ment together with cultural results obtained follow ing inoculation with a standard loop.

Provided that fresh or refrigerated specimens were received, Christie (personal oommunication) cons ders that routine examination was at least as accurate as any of the other procedures. Th method although not allowing discrimination between infected and contaminated urine, was cono sidered more than adequate for diagnostic purposes when taken in conjunction with the clinical findings

\section{Results}

\section{Disc Sensitivity Tests}

The results of routine disc sensitivity tes of 2,628 consecutive isolates are shown if Table I. 
TABLE I

Ampicillin Sensitivity of 2,628 Consecutive Routine Isolates

\section{Organism}

Staphylococcus aureus

Streptococcus fæcalis

Nocardia asteroides

Escherichia coli

Aerobacter spp.

Proteus spp.

Serratia marcescens

Salmonella spp.

These results parallel closely those of other authors. The low incidence of sensitivity of Staphylococcus aureus is because most of the strains tested were already known to be resistant to penicillin $G$, i.e. ampicillin sensitivity was determined on sub-culture and would be expected in any case to be low. It can readily be appreciated from the table that a considerable number of infections due to gram-negative organisms are quite definitely resistant to ampicillin by in vitro testing.
Acute Cystitis

The results in a total of 11 cases are presented in Table II.

The dose employed varied from 250 to 750 mg. six-hourly for a mean duration of six days. A considerable variety and combination of infecting organisms presented, yet all cases were cured at both the clinical and laboratory level with ampicillin treatment. Case number 30 had been previously treated with four other antibacterials without effect.

Recurrent Cystitis

Four cases of recurrent cystitis are detailed in Table III.

As with all of the recurrent infections reported in this series, these patients had all been given alternative antibiotic therapy before being placed on ampicillin. Three types of organism were involved, one case being a mixed infection. The dose of ampicillin employed varied from 500 to $750 \mathrm{mg}$. sixhourly. Two patients failed to respond to ampicillin with either clinical or laboratory improvement. The Esch. coli of Case 48 was

TABLE II

Acute Cystitis

\begin{tabular}{lccccc}
\hline Case No. & $\begin{array}{c}\text { Infecting } \\
\text { Organism }\end{array}$ & $\begin{array}{c}\text { Dose in mg. } \\
\text { q.i.d. }\end{array}$ & $\begin{array}{c}\text { Days on } \\
\text { Ampicillin }\end{array}$ & Result & $\begin{array}{c}\text { Previous } \\
\text { Treatment* }\end{array}$ \\
1, 6, 13,16 & Esch. coli & 500 & Av. 6 & Cured & nil \\
Esch. coli 44 & 500 & Av. 6 & Cured & nil \\
30 & Str. fæcalis & 500 & 7 & Cured & FCTS \\
46 & Esch. coli & 250 & 5 & Cured & nil \\
33 & $\begin{array}{c}\text { Esch. coli } \\
\text { Proteus spp. }\end{array}$ & 750 & 7 & Cured & nil \\
47 & $\begin{array}{c}\text { Proteus spp. } \\
\text { Str. fæcalis }\end{array}$ & 750 & 6 & Cured & nil \\
\hline
\end{tabular}

${ }^{*} \mathrm{~F}-$ Furadantin, $\mathrm{C}-$ Chloramphenicol, $\mathrm{T}-$ Tetra cycline, $\mathrm{S}-$ Sulphonamide

TABLE III

Recurrent Cystitis

\begin{tabular}{cccccc}
\hline Case No. & $\begin{array}{c}\text { Infecting } \\
\text { Organism }\end{array}$ & $\begin{array}{c}\text { Dose in mg. } \\
\text { q.i.d. }\end{array}$ & $\begin{array}{c}\text { Days on } \\
\text { Ampicillin }\end{array}$ & Result & $\begin{array}{c}\text { Previous } \\
\text { Treatment* }\end{array}$ \\
$4 \dagger$ & Esch. coli & 500 & 2 & NI & FS \\
38 & Esch. coli & 500 & 6 & Cured & CT \\
3 & Str. fæcalis & 500 & 5 & Cured & TF \\
48 & Esch. coli & 750 & 10 & NI & TS \\
& Aerobacter spp. & & & & \\
\hline
\end{tabular}

${ }^{*} \mathrm{~F}$ - Furadantin, $\mathrm{S}-$ Sulphonamide. $\mathrm{C}-$ Chloram phenicol, $\mathrm{T}-$ Tetracycline

$\dagger$ Treatment stopped because of vomiting, NI-Not improved. 
TABLE IV

Acute Pyelonephritis

\begin{tabular}{|c|c|c|c|c|c|}
\hline Case No. & $\begin{array}{l}\text { Infecting } \\
\text { Organism }\end{array}$ & $\begin{array}{l}\text { Dose in mg. } \\
\text { q.i.d. }\end{array}$ & $\begin{array}{l}\text { Days on } \\
\text { Ampicillin }\end{array}$ & Result & $\begin{array}{c}\text { Previous } \\
\text { Treatment }\end{array}$ \\
\hline $\begin{array}{l}5,8,40,45 \\
15,22,36 \\
2 \dagger, 12,35 \\
9\end{array}$ & $\begin{array}{l}\text { Proteus spp. } \\
\text { Esch. coli } \\
\text { Esch. coli } \\
\text { Esch. coli } \\
\text { Str. fæcalis }\end{array}$ & $\begin{array}{l}500 \\
500 \\
500 \\
750\end{array}$ & $\begin{array}{l}\text { Av. } 5 \\
\text { Av. } 6 \\
\text { Av. } 6 \\
10\end{array}$ & $\begin{array}{l}\text { Cured } \\
\text { Cured } \\
\text { NI } \\
\text { NI }\end{array}$ & $\begin{array}{l}\text { nil } \\
\text { nil } \\
\text { nil } \\
\text { nil }\end{array}$ \\
\hline $\begin{array}{l}17 \\
26 \ddagger\end{array}$ & $\begin{array}{l}\text { Esch. coli } \\
\text { Esch. coli } \\
\text { Proteus spp. }\end{array}$ & $\begin{array}{l}750 \\
750\end{array}$ & $\begin{array}{l}15 \\
21\end{array}$ & $\begin{array}{c}\text { Cured } \\
\text { Improved }\end{array}$ & $\begin{array}{l}\mathrm{FS} \\
\mathrm{C}\end{array}$ \\
\hline 27 & $\begin{array}{l}\text { Ps. pyocyanea } \\
\text { Esch. coli } \\
\text { Proteus spp. }\end{array}$ & 500 & 5 & Cured & TF \\
\hline $\begin{array}{l}29^{\circ} \\
31 \\
34 \\
39\end{array}$ & $\begin{array}{l}\text { Aerobacter spp. } \\
\text { Esch. coli } \\
\text { Aerobacter spp. } \\
\text { Aerobacter spp. }\end{array}$ & $\begin{array}{l}500 \\
750 \\
500 \\
750\end{array}$ & $\begin{array}{r}7 \\
11 \\
10 \\
10\end{array}$ & $\begin{array}{l}\text { Cured } \\
\text { Cured } \\
\text { NI } \\
\text { Cured }\end{array}$ & $\begin{array}{c}\text { nil } \\
\text { FC } \\
\text { CTS } \\
\text { TC }\end{array}$ \\
\hline
\end{tabular}

*F - Furadantin, C - Chloramphenicol, T - Tetracycline, S - Sulphonamide

tCase 2 developed uticaria. NI - not improved.

tCombined treatment with kanamycin.

${ }^{\circ}$ Combined treatment with furadantin.

TABLE V

Urinary Tract Infections

\begin{tabular}{|c|c|c|c|c|c|}
\hline Case No. & $\begin{array}{l}\text { Infecting } \\
\text { Organism }\end{array}$ & $\begin{array}{l}\text { Dose in mig. } \\
\text { q.i.d. }\end{array}$ & $\begin{array}{l}\text { Days on } \\
\text { Ampicillin }\end{array}$ & Result & $\begin{array}{c}\text { Previous } \\
\text { Treatment* }\end{array}$ \\
\hline $\begin{array}{l}10,11,42 \\
21 \\
24 \dagger \\
28 \\
7\end{array}$ & $\begin{array}{l}\text { Esch. coli } \\
\text { Esch. coli } \\
\text { Esch. coli } \\
\text { Proteus spp. } \\
\text { Esch. coli } \\
\text { Proteus spp. }\end{array}$ & $\begin{array}{l}500 \\
500 \\
750 \\
500 \\
500\end{array}$ & $\begin{array}{c}\text { Av. } 5 \\
6 \\
10 \\
6 \\
7\end{array}$ & $\begin{array}{c}\text { Cured } \\
\text { Cured } \\
\text { NI } \\
\text { Cured } \\
\text { Improved }\end{array}$ & $\begin{array}{l}\text { nil } \\
\text { FS } \\
\text { nil } \\
\text { nil } \\
\text { nil }\end{array}$ \\
\hline 43 & Esch. coli & 500 & 7 & NI & nil \\
\hline 25 & $\begin{array}{l}\text { Proteus spp. } \\
\text { Esch. coli } \\
\text { Staph. aureus }\end{array}$ & 750 & 42 & Cured & TC1 \\
\hline
\end{tabular}

*F - Furadantin, $\mathrm{S}$ - Sulphonamide, $\mathrm{T}-$ Tetracycline, $\mathrm{Cl}$ - Cloxacillin.

†Died from aplastic anæmia. NI - not improved.

resistant to ampicillin in vitro though the Aerobacter aerogenes was sensitive; yet despite a high dosage for 10 days no remission occurred and the drug was discontinued. Case four although cured in two days was forced to stop treatment because of vomiting. This was considered to be due to ampicillin and a test dose given later elicited the same response plus diarrhoea. Duration of treatment in this group was two to ten days with a mean of 6.5 days.

\section{Acute Pyelonephritis}

Table IV includes the results of ampicillin treatment in a series of 18 patients with acute pyelonephritis.
The range of infecting organisms is wide and includes three cases where Aerobacter aerogenes was isolated; two of these patients responded to treatment. Five patients had $\bigcirc$ been on previous treatment with other antibiotics to no avail. All but five of the 18 을 cases were cured with ampicillin therapy, $\frac{D}{0}$ (one patient had kanamycin concurrently) and a further case was classified as only improved ${ }^{\circ}$ because despite a sterile urine, some symptoms referable to the urinary tract persisted.

Dosage of the drug varied from 500 to $750^{\mathrm{c}}$ mg. six-hourly and treatment extended from? 4-15 days with a mean of seven days.

Case two developed a generalised urticaria $\Phi_{\overparen{D}}$ whilst on treatment with ampicillin but this 
TABLE VंI

Recurrent Urinary Tract Infections

\begin{tabular}{cccccc}
\hline Case No. & $\begin{array}{c}\text { Infecting } \\
\text { Organism }\end{array}$ & $\begin{array}{c}\text { Dose in mg. } \\
\text { q.i.d. }\end{array}$ & $\begin{array}{c}\text { Days on } \\
\text { Ampicillin }\end{array}$ & Result & $\begin{array}{c}\text { Previous } \\
\text { Treatment* }\end{array}$ \\
18 & $\begin{array}{c}\text { Esch. coli } \\
\text { Proteus spp. }\end{array}$ & 250 & 10 & Cured & FC \\
$19 \dagger$ & $\begin{array}{c}\text { Esch. coli } \\
\text { Esch. coli }\end{array}$ & 500 & 7 & Cured & FCSt \\
41 & $\begin{array}{c}\text { Proteus spp. } \\
\text { Esch. coli } \\
\text { Str. fæcalis }\end{array}$ & 750 & 7 & Cured & CTS \\
& Cured & & & & \\
\hline
\end{tabular}

${ }^{*} \mathrm{~F}$ - Furadantin, C - Chloramphenicol, St - Streptomycin, T - Tetracycline, S - Sulphonamide. $\dagger$ Urticaria, but treatment continued.

regressed with the exhibition of antihistamines. The Esch. coli infecting Case number 12 was resistant to ampicillin on in vitro testing.

\section{Recurrent Pyelonephritis}

There were only two cases of this disease so they are not tabulated. Case 23, previously treated with sulphonamides was infected by Esch. coli and was given ampicillin $500 \mathrm{mg}$. six-hourly for seven days without improvement at either the clinical or laboratory level.

Case 32 had previously been given both tetracyclines and sulphonamides for a recurrent Esch. coli pyelonephritis. $\mathrm{He}$ was given ampicillin $500 \mathrm{mg}$. six-hourly for six days without improvement. A known case of aplastic anæmia he died whilst on treatment but probably not because of his urinary tract infection.

\section{Urinary Tract Infection}

Acute infections of the urinary tract totalled nine cases as shown in Table V.

A broad range of infecting organisms was involved. Six patients were cured with ampicillin and a seventh was improved but not cured symptomatically, despite a sterile urine. Of the two cases in which treatment failed, one was a terminal aplastic anæmia who died, and the other was a mixed infection of Esch. coli and proteus who on the basis of in vitro testing should have responded to treatment. The dosage ranged from 500 to $750 \mathrm{mg}$. six-hourly and the duration of treatment was from 4-42 days with a mean of ten days. If Case 25 (42 days) is excluded from the duration tabulation, the mean becomes 6.5 days which more nearly approximates the other groups so far reported.

\section{Recurrent Urinary Tract Infections}

The results in a small series of four cases are shown in Table VI.

Despite the fact that three of the cases were mixed infections and that one of these was treated with only $1 \mathrm{~g}$. of ampicillin daily, all responded to treatment. Although this result is encouraging, the number of cases is too small to draw a meaningful conclusion. The dose varied from $250-750 \mathrm{mg}$. six-hourly over a time period of 5-10 days with a mean of seven days. Case 19 developed a mild urticaria.

\section{Discussion \\ Clinical Findings}

As mentioned before there is a paucity of reported clinical material on the use of ampicillin in the treatment of urinary tract infections. Stewart et al (1961) were the first to describe its use in a group of eight children at a dosage of $50-100 \mathrm{mg}$. $/ \mathrm{Kg}$./day. The urine beoame sterile in evẹry case but two were reinfected three weeks later, a success rate of 80 per cent. Four of the group had been previously treated with other antibiotics.

Brumfitt, Percival and Carter (1962) treated a series of 45 acute urinary tract infections and showed $93 \%$ of the urines to be sterile 48 hours after treatment ceased, but the long term follow-up reduced the cure rate to a still impressive $84 \%$. In both instances the results were appreciably better than those obtained in a group of 34 patients treated with nitrofurantoin. These workers noted that the difference in results between the two groups was largely accounted for by the sensitivity of Proteus mirabilis to ampicillin. 
TABLE VII

Published Results of Ampicillin Therapy in Urinary Tract Infections

\begin{tabular}{|c|c|c|c|c|c|c|c|}
\hline Authors & $\begin{array}{l}\text { No. of } \\
\text { Cases }\end{array}$ & Disease & Dosage & $\%$ & 6 Cured & $\begin{array}{l}\text { Previous } \\
\text { Treatment* }\end{array}$ & $\begin{array}{c}\text { Side } \\
\text { Effects }\end{array}$ \\
\hline Stewart, et al. (1961) & 8 & UTI & $\begin{array}{c}50-100 \\
\mathrm{mg} / \mathrm{Kg} . / \mathrm{day}\end{array}$ & $(20 \%$ & $\begin{array}{l}100 \% \\
\text { reinfected) }\end{array}$ & 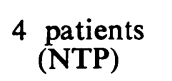 & 3 \\
\hline Brumfitt, et al. (1962) & 45 & Acute UTI & $\begin{array}{l}500 \mathrm{mg} . \\
\text { t.d.s. }\end{array}$ & $(9 \%$ & $\begin{array}{l}93 \% \\
\text { reinfected) }\end{array}$ & & 2 \\
\hline Stratford (1962) & 9 & UTI & $\begin{array}{c}250-750 \mathrm{mg} . \\
\text { q.i.d. }\end{array}$ & & $89 \%$ & & 1 \\
\hline Lockey, et al. (1962) & 16 & UTI & $\begin{array}{c}250-500 \mathrm{mg} . \\
\text { q.i.d. }\end{array}$ & $(14 \%$ & $\begin{array}{l}100 \% \\
\text { reinfected) }\end{array}$ & $\begin{array}{c}6 \text { patients } \\
\text { (NSPTC) }\end{array}$ & 2 \\
\hline Trafford, et al. (1962) & 41 & UTI & $\begin{array}{l}500-1,000 \\
\text { mg. q.i.d. }\end{array}$ & & $89 \%$ & & 5 \\
\hline $\begin{array}{l}\text { Höffler \& Scheler } \\
(1963)\end{array}$ & 56 & Chronic UTI & $1-4 \mathrm{gm} . /$ day & & $42 \% \dagger$ & NCE & 7 \\
\hline Stratford (1964) & 48 & UTI & $\begin{array}{c}250-750 \mathrm{mg} . \\
\text { q.i.d. }\end{array}$ & & $75 \%$ & NSTC & 3 \\
\hline
\end{tabular}

${ }^{*} \mathrm{~N}-$ Nitrofurantoin, $\mathrm{T}-$ Tetracycline, $\mathrm{P}-$ Penicillin, $\mathrm{S}-$ Sulphonamide, $\mathrm{C}-$ Chloramphenicol,

E - Erythromycin.

$\nmid$ Treatment not based on antibiogram sensitivity.

This has also been our experience in Melbourne, where Proteus mirabilis accounts for the greater proportions of strains of Proteus spp. isolated in hospitals.

Lockey, Eaton and Compston (1962) reported a series of 16 patients with urinary tract infections, six of whom had previous antibiotic therapy. The dose they used was $500 \mathrm{mg}$. six-hourly for 5-8 days. Most of the infections were due to what were loosely termed coliform bacilli, and two were resistant to ampicillin in vitro before treatment started. If these are excluded the success rate is $100 \%$ in this series, although in two cases reinfection occurred quite promptly after ceasing the drug. This gave a long-term cure rate of $86 \%$. A number of the patients successfully treated could be considered difficult cases from the point of view of obtaining even a laboratory cure, so their result is impressive.

Also in 1962 Trafford, Maclaren, Lillicrap, Barnes, Houston and Knox presented the results of ampicillin therapy in 41 cases of urinary tract infections. By inference their patients were simple acute infections. The dose employed varied from $2-4 \mathrm{~g}$. daily for 5-7 days. The result was a cure rate of $58 \%$, but when organisms originally resistant to ampicillin are excluded the success rate increases to $89 \%$. It is of interest to note the failure of the drug in three cases where Aerobacter aerogenes was the infectung organism and compare their results with thesse reported earlier in this paper.

In ten cases with mixed infections of four were cleared by ampicillin, whereas im our series of 12 patients with mixed infections only three failed to improve with the same drug.

Again in 1962, Stratford reported nine case of urinary tract infection treated with $250 \mathrm{t} \overrightarrow{\widehat{\Theta}}$ $750 \mathrm{mg}$. of ampicillin six-hourly. Eight of these were cured, a success rate of $89 \%$.

The last published series of urinary infections treated with ampicillin is that of Höffles and Scheler (1963). In this series of 56 cases most were complicated or chronic infections of the urinary tract. These authors realizes. that the evaluation of success in such cases if more difficult and less distinct than in un complicated acute infections, yet their cure rate was a staggering $42 \%$. This resul is all the more exciting when one considers. that Garrod, Shooter and Curwen (1954) ant Kass (1955) both felt that control in such cases is only achieved in about $10 \%$ of patients. The dosage used in this series was 1-4 g. daily for an average of 10-14 days.

In the series of 48 patients with acufe or recurrent acute urinary tract infectio previously described in this paper the success 
rate was $75 \%$ which is much in accord with the above results. On an average the dose employed was $500 \mathrm{mg}$. six-hourly for a mean period of eight days.

Table VII summarises the published results of ampicillin therapy in urinary infections, and out of 215 patients 144 were cured, a success rate of $67 \%$, but it must be remembered that this figure could be improved if the chronic infections of the large series described by Höffler and Scheler (1963) was not included.

\section{Side-effects}

No antibiotic is free from side-effects, however mild, and in this respect ampicillin is no exception. Stewart et al. (1961) in their eight cases encountered three patients with urticaria in whom the intradermal test proved negative. This apparent inconsistency highlights the difficulty of predicting a reaction to penicillin as has already been well discussed by Trinca (1962). Lockey and her colleagues (1962) reported two cases of urticaria in 16 patients, and Brumfitt et al. (1962) had one quite severe reaction with stridor, fever and erythema multiforme and yet another patient developed a monilial vaginitis. Trafford et al. (1962) in their series had five instances of side-effects where either the drug could not be taken or else had to be stopped. In 1962 I had one case of drug rash develop. Höffler and Scheler (1963) reported that seven of their 56 patients developed skin reactions of one sort or another; all occurred between the 10th and 14th days of treatment and disappeared when the drug was stopped. They also noted the fallibility of skin testing as a measure for determining penicilin sensitivity. These same authors also quote Zylka, Christner and Moers (1962) as noting nine skin reactions in 83 patients.

In the 48 cases I have presented here, three patients showed side effects, one of whom vomited and two developed urticarial reactions. A fairly common complaint amongst my patients on ampicillin is of an unpleasant tasting eructation following the capsules, and frequently patients mention that they have noticed that their urine posseses an acrid or musty smell. However, neither of these complaints is severe enough to warrant discontinuing the drug.

In all of the published series the incidence of side-effects is about $10 \%$ but these are mainly urticarial in nature and disappear when the drug is stopped. so we can conclude that ampicillin is fairly innocuous from the point of view of side-effects.

\section{General Considerations}

Stewart et al. (1961) quoted a figure of $20-60 \%$ of the daily dose of ampicillin as being recoverable from the urine, and Knudsen et al. (1961) found $30 \%$ of the dose excreted in six hours. Brumfitt et al. (1962) quotes the figures of $18-40 \%$ and Stratford (1962) found $50 \%$. At all events the urinary concentrations achieved by oral administration are very high so one can expect the clinical result to be good against sensitive organisms located superficially in the urinary tract. The adequate tissue levels obtainable promise, as has been suggested by Ross (1964) that even where the infection lies in the renal substance itself, ampicillin may well prove more effective than other conventional urinary antiseptics.

In addition to the above, the fact that the drug is bactericidal would appear to make ampicillin the treatment of choice for susceptible urinary tract infections, and there seems little doubt from all the reported series that longer courses of treatment will tend to lessen the recurrence rate. This observation of course applies to drugs other than ampicillin. Adequate and regular follow-up studies are mandatory with urinary infections, perhaps more so than with any other group of diseases. It would seem that a dose of at least $2 \mathrm{~g}$. of ampicillin daily for a minimum of ten days could be expected to achieve a high cure rate whilst at the same time reducing recurrent infection. Prolonged courses may be necessary where chronic disease or gross structural abnormality exists.

\section{Summary}

1. A series of 2,628 laboratory isolates were examined for ampicillin sensitivity. This confirmed the drug's in vitro value in Gram-negative infections.

2. A series of 48 patients with acute or recurrent acute urinary tract infections is described with a successful cure rate of $75 \%$. Nine out of 12 mixed infections were cured, and the fact that the infection was recurrent did not influence the therapeutic outcome.

3. Side-effects of the drug are discussed and occur in $10 \%$ of published cases, generally in the form of urticarial reactions 
4. Ampicillin appears to be a most valuable antibiotic for urinary tract infections but courses of the drug should probably be for a minimum of 10 days with adequate laboratory follow-up studies.

I wish to thank my colleagues and Dr. W. M. C. Keane, Medical Superintendent of St. Vincent's Hospital, Melbourne, both for their co-operation and also for permission to present these results. My thanks are due to Miss E. Binns and her staff of the Medical Records Department of this hospital. Mrs. S. Dixson gave me expert technical assistance. The Hospitals and Charities Commission of Victoria provided financial help.

\section{REFERENCES}

Braude, A. I., and Berkowitz, H. (1961): J. Lab. clin. Med., 57, 490.

Brown, D. M., and ACred, P. (1961): Brit. med J., ii, 197.

Brumfitt, W., Percival, A., Carter, M. J. (1962): Lancet, i, 130.
Christie, R. (1963): Personal Communication.

Garrod, L. P., Shooter, R. A., and Curwen, M. P.ב (1954): Brit. med. J., ii, 1003.

HÖFFLER, D., and SCHELER, F. (1963): Disch. med. Weld., $20,1126$.

Kass, E. H. (1955): Amer. J. Med., 18, 764. (1961): Brit. med. J., ii, 198.

LOCKEY, E., EATON, B. R., and COMPSTON, N. (1962): Brit. J. clin. Pract., 16, 13.

Rolinson, G. N., and STEVenS, S. (1961): Brit. med. J., ii, 191.

Ross, E. J. (1964): Prescriber's Journal, 3, 102.

Simmons, N. A., and Williams, J. D. (1962): Lancet, i, 1377 .

Stewart, G. T., Coles, H. M. T., Nixon, H. H., and HoLT, R. J. (1961): Brit. med. J., ii, 200.

StRATFORD, B. C. (1962): Med. J. Aust., 2, 414.

Trafford, J. A. P., Maclaren, D. M., Lillicrapco D. A., Barnes, R. D. S., Houston, J. C., and 3 . KNOX, R. (1962): Lancet, i, 987.

TrincA, J. C. (1962): Med. J. Aust., 2, 428.

Zylka, W., Christener, M., and Moers, H. (1962): Arzneimittel-Forsch., 12, 803.

\title{
AMPICILLIN IN BACTERIURIA AND PYELONEPHRITIS OF PREGNANCY
}

\author{
Priscilla KinCaid-Smith* \\ Senior Associate in Medicine, Department of Medicine, University of Melbourne. \\ Honorary Physician, Queen Victoria Hospital, Melbourne.
}

ASYMPTOMATIC bacteriuria is present in about six per cent of pregnant women and about half these women develop pyelonephritis of pregnancy. Kass' (1960, 1962) findings suggested that pyelonephritis of pregnancy could be virtually eliminated by treatment of bacteriuria, because no pyelonephritis occurred in his non-bacteriuric patients or in those receiving treatment for bacteriuria. He also found that the high incidence of prematurity and perinatal mortality in his bacteriuric patients was reduced by treatment. Because of the important implications of these observations and because other findings had not been entirely in agreement with those of Kass (Kaitz and Hodder 1961, Turck, Goffe and Petersdorf 1962, Turner, 1961) we instituted a double blind controlled trial of anti-bacterial drugs in pregnancy bacteriuria.

Our own findings in a pilot study like those

*In receipt of a Research Fellowship from the National Health and Medical Research Council of Australia. of Kass (1960) suggested that continuouss administration of an anti-bacterial drug waso necessary to control bacteriuria. In selecting a drug for continuous administration during pregnancy, ampicillin seemed a good choice in that it was effective in urinary tract infec tions and being a penicillin was unlikely to have serious toxic effects on mother or fœtus. Sufficient supplies were not available, how:ever, and ampicillin was therefore used onlye. in infections resistant to sulphonamides, sulphamethoxydiazine being used to control the bacteriuria in most patients.

\section{Methods}

Bacterial counts by a spread plate technique $N$ were done on mid-stream urine specimens collected at the first ante-natal visit in 4,000 women. Six 0 per cent of these showed bacteriuria ( $>100,000 \mathrm{\omega}$ organisms $/ \mathrm{ml}$.). Patients with bacteriuria were allo-o cated at random to placebo or treatment and seen< at monthly intervals in a special clinic for clinical, bacteriological and biochemical assessment. In addition to bacterial counts, quantitative leucocyte? counts were performed on urine specimens. 7 